Pak. j. sci. ind. res. Ser. B: biol. sci. 201356 (3) 137-141

\title{
Enhancement of the Nutritional Value of Whey Drink by Supplementing with Leaves of Moringa oleifera
}

\author{
Muhammad Nadeem*, Imtiaz Hussain, Muhammad Abdullah and Fazal Rehman \\ Department of Dairy Technology, University of Veterinary and Animal Science, Lahore, Pakistan
}

(received April 16, 2012; revised April 10, 2013; accepted April 11, 2013)

\begin{abstract}
The effect of supplementing Moringa oleifera leaf powder (MOLP) on the nutritional and sensory characteristics of whey drink was investigated. Whey drink was supplemented with MOLP at four different concentrations i.e., $1 \% \operatorname{MOLP}\left(\mathrm{T}_{1}\right), 2 \% \operatorname{MOLP}\left(\mathrm{T}_{2}\right), 3 \% \operatorname{MOLP}\left(\mathrm{T}_{3}\right), 4 \% \operatorname{MOLP}\left(\mathrm{T}_{4}\right)$ and compared with a control $\left(\mathrm{T}_{0}\right)$. The addition of MOLP at any level did not have a negative effect on $\mathrm{pH}$ and acidity of whey drink. Iron content of $\mathrm{T}_{4}$ increased from 0.17 to $115 \mathrm{mg} / 100 \mathrm{~mL}$, total phenolic content of MOLP was $7.4 \mathrm{~g} / 100 \mathrm{~g}$ on dry weight basis (gallic acid). Vitamin $\mathrm{C}$ increased from 1.46 to $2.20 \mathrm{mg} / 100 \mathrm{~g}$ in $\mathrm{T}_{4}$. The overall acceptability score of $\mathrm{T}_{4}$ was 6.9 out 9 (total score) which was more than $76 \%$. These results suggest that nutritional value of whey can be increased by supplementing with $4 \%$ dry leaves of $M$. oleifera in the form of a whey based drink with acceptable sensory characteristics.
\end{abstract}

Keywords: Moringa oleifera, leaf powder, whey drink, iron, malnutrition

\section{Introduction}

Malnutrition results in retarded physical and mental growth as well as lack of resistance against diseases, whereas, protein deficiency results in poor health and reduced capacity for physical work (NNS, 2004). Plants have natural antioxidants and polyphenolic compounds that have anticarinogenic, cardiac and hepatic protective activity (Jeong et al., 2004; Kris-Etherton et al., 2002; Middleton et al., 2000). M. oleifera is fast growing tree and its flowers, leaves and pods are consumed as vegetable and tender roots are preserved in the form of tasty pickles (Anwar et al., 2007). It has high contents of protein and vitamins (Juliani et al., 2009; Quarcoo, 2008; Fuglie, 1999).

Whey is the by-product of cheese, containing nearly half of the total solids present in milk (Walzem et al., 2002). Cheese manufacturing units of Pakistan throw thousands of liters of untreated whey into the drain on daily basis which must be treated before discharge into the environment (Marwaha and Kennedy, 1998). Soft drinks may also be manufactured from whey by making use of different types of stabilizers and fruit concentrates of orange, apple, banana, mango and lemon (Niketic and Marinkovic, 1984). Keeping in view the utilization of whey, the present investigation was aimed to prepare nutritious whey drink by exploiting the massive nutritional potential of M. oleifera.

*Author for correspondence; E-mail:sheikhnadeem@live.com

\section{Materials and Methods}

Materials. Dried M. oleifera leaves were ground in a laboratory scale grinder (Moulinex), sieved through mesh size 50, stored in amber colour glass bottles, sealed and stored at $-40{ }^{\circ} \mathrm{C}$ till further usage in this study. All the chemicals used in this study were HPLC grade and obtained from Sigma Chemical Co. (St. Louis $\mathrm{MO})$.

Treatments. Moringa oleifera leaf powder (MOLP) was incorporated into whey drink at four different concentrations i.e., $1 \% \operatorname{MOLP}\left(\mathrm{T}_{1}\right), 2 \% \operatorname{MOLP}\left(\mathrm{T}_{2}\right)$, $3 \% \operatorname{MOLP}\left(\mathrm{T}_{3}\right), 4 \% \operatorname{MOLP}\left(\mathrm{T}_{4}\right)$, and compared with a control $\left(\mathrm{T}_{0}\right)$. The formulation of control comprised of banana pulp $5 \%$, sugar $5 \%$, citric acid ( $20 \%$ solution) $0.5 \%$, carageenan $0.25 \%$ and whey to make volume up to the mark, colour and flavour $1 \mathrm{~mL} / \mathrm{L}$. All the ingredients were dissolved in the whey, pasteurised in the beakers at $65^{\circ} \mathrm{C}$ for $30 \mathrm{~min}$, immediately cooled down, filled in clean sanitised pet bottles and stored at $4{ }^{\circ} \mathrm{C}$ for further analysis. Each treatment was replicated three times.

Analysis. Fat, pH, acidity, protein, lactose, ash content and total solids were determined by following the respective methods AOAC 7.093, AOAC 7.094 and AOAC 7.095 (AOAC, 2000). Ca, K and Mg were analysed on atomic absorption spectrophotometer (Model: AA240, Varian, Australia) briefly, $5 \mathrm{~g}$ sample was taken into a conical flask, $10 \mathrm{~mL}$ of concentrated 
nitric acid was added and contents of the flask were heated for $20 \mathrm{~min}$. After cooling, $5 \mathrm{~mL}$ perchloric acid was added and again heated vigorously till the volume was reduced to $2-3 \mathrm{~mL}$ followed by cooling. The contents were then diluted in $50 \mathrm{~mL}$ volumetric flask by using distilled water. Absorbance of each mineral was determined on the respective wave length, also the unknown concentration determined by constructing calibration curve using 8 standards of each mineral $\left(R^{2}=0.9891\right.$ to 0.9961$)$. Concentration of iron was determined by using the standard method AOAC 999.11 of AOAC (2000). Vitamin assay was performed on HPLC by following the respective methods AOAC 971.30, AOAC 948.26, and AOAC 975.42 (AOAC, 2000). Free fatty acids and peroxide values were determined by using standard methods $\mathrm{cd} \mathrm{8-53}$ and $\mathrm{cd}$ 1-25 of Firestone (1997). For the determination of total phenolic contents of MOLP, $1 \mathrm{~mL}$ (methanolic extract of leaf powder) was poured into $11 \mathrm{~mL}$ screw capped test tube, $2 \mathrm{~mL}$ (0.2-molar) folin ciocalteu, $2 \mathrm{~mL}$ sodium carbonate $(7.5 \%)$ added, mixed and stored in dark for $20 \mathrm{~min}$ at ambient temperature and absorbance measured at $765-\mathrm{nm}$ in visible region on a double beam spectrophotometer (Shidmadzu, Japan). The concentration of phenolic compounds was measured on a standard curve constructed by using gallic acid as standard $\left(R^{2}=0.9943\right)$ by following the method of Anwar et al. (2007). The sensory evaluation of whey drink was conducted by a panel of 10 trained judges performed on a 9 point hedonic scale (1- the worst; 9the best) as prescribed by Larmond (1987). The samples were evaluated for texture, taste, smell and overall acceptability. Samples were presented in glasses, coded with three digit random numbers and all servings were completely randomized. The data of triplicate experiments designed completely randomized (CRD). All data expressed as Mean $\pm \mathrm{SD}$, the significant difference among the treatments calculated by using Duncan's Multiple Range Test SAS 9.1 Statistical Software.

\section{Results and Discussion}

Composition of whey drink supplemented with $M$. oleifera leaves. The results of chemical composition of whey drink show that fat, protein, lactose, ash and total solids content were $0.42 \%, 0.65 \%, 4.38 \%, 0.58 \%$ and $6.11 \%$. Addition of MOLP at all the four levels did not have any negative effect on $\mathrm{pH}$ and acidity of supplemented whey drink (Table 1).

As the concentration of MOLP increased to $2 \%$, fat content increased significantly $(\mathrm{P}<0.05)$. The highest fat content $0.64 \%$ observed in $\mathrm{T}_{4}$ which was $52 \%$ over the control. Protein content of the supplemented whey drinks increased in a concentration dependent manner. Increase in protein content was $164 \%$ in $\mathrm{T}_{4}$ as compared to the control. The increase in fat and protein content was due to the presence of higher concentration of these constituents in MOLP. Addition of MOLP at all levels increased the ash content of whey drinks significantly $(\mathrm{P}<0.05), \mathrm{T}_{1}$ and $\mathrm{T}_{2}$ comparison with each other $(\mathrm{P}>0.05)$, increased to 52 and $65 \%$ in $\mathrm{T}_{3}$ and $\mathrm{T}_{4}$, respectively, as compared to the control. Increasing trend was observed in total solids with increased level of supplementation. The highest total solids recorded in $\mathrm{T}_{4}$ (16.93\%) followed by $\mathrm{T}_{3}(15.84 \%)$ and $\mathrm{T}_{2}(14.89 \%)$.

Total phenolic contents: Total phenolic content of MOLP was $7.4 \mathrm{~g} / 100 \mathrm{~g}$ on dry matter basis (GAE). The total phenolic contents of Sesamum indicum cake extract was $1.94 \%$ on dry matter basis (Mohdaly et al., 2011). In M. olifera concerentration of phenolic compounds was considerably higher than $S$. indicum (Mohdaly et al., 2011) and canola hull (Naczk and Shahidi, 1998).

Minerals content of whey drink supplemented with M. oleifera leaves. Calcium content of all the treatments

Table 1. Effect of MOLP supplementation on composition of whey drink

\begin{tabular}{|c|c|c|c|c|c|c|c|}
\hline Treatments & $\mathrm{pH}$ & Acidity & Fat & $\begin{array}{l}\text { Protein } \\
(\%)\end{array}$ & Lactose & Ash & TS \\
\hline $\mathrm{T}_{0}$ & $6.43 \pm 0.99^{\mathrm{a}}$ & $0.23 \pm 0.10^{\mathrm{a}}$ & $0.42 \pm 0.08^{\mathrm{c}}$ & $0.67 \pm 0.13^{\mathrm{e}}$ & $4.65 \pm 0.21^{\mathrm{a}}$ & $0.60 \pm 0.14^{\mathrm{c}}$ & $12.75 \pm 0.21^{\mathrm{e}}$ \\
\hline $\mathrm{T}_{1}$ & $6.37 \pm 0.83^{\mathrm{a}}$ & $0.24 \pm 0.06^{\mathrm{a}}$ & $0.45 \pm 0.16^{\mathrm{c}}$ & $0.94 \pm 0.11^{\mathrm{d}}$ & $4.56 \pm 0.15^{\mathrm{a}}$ & $0.71 \pm 0.22^{\mathrm{b}}$ & $13.80 \pm 0.18^{\mathrm{d}}$ \\
\hline $\mathrm{T}_{2}$ & $6.38 \pm 0.66^{\mathrm{a}}$ & $0.24 \pm 0.09^{\mathrm{a}}$ & $0.51 \pm 0.14^{\mathrm{b}}$ & $1.19 \pm 0.34^{\mathrm{c}}$ & $4.39 \pm 0.11^{\mathrm{b}}$ & $0.85 \pm 0.12^{\mathrm{b}}$ & $14.89 \pm 0.35^{\mathrm{c}}$ \\
\hline $\mathrm{T}_{3}$ & $6.35 \pm 0.77^{\mathrm{a}}$ & $0.25 \pm 0.14^{\mathrm{a}}$ & $0.55 \pm 0.11^{\mathrm{b}}$ & $1.46 \pm 0.29^{b}$ & $4.31 \pm 0.08^{b}$ & $0.91 \pm 0.18^{\mathrm{a}}$ & $15.84 \pm 0.42^{b}$ \\
\hline $\mathrm{T}_{4}$ & $6.38 \pm 1.02^{\mathrm{a}}$ & $0.24 \pm 0.12^{\mathrm{a}}$ & $0.64 \pm 0.19^{\mathrm{a}}$ & $1.73 \pm 0.43^{\mathrm{a}}$ & $4.25 \pm 0.14^{b}$ & $0.99 \pm 0.24^{\mathrm{a}}$ & $16.93 \pm 0.29^{a}$ \\
\hline
\end{tabular}

Means of triplicate experiment; means with same letters in same column are statistically non-significat $(\mathrm{P}>0.05)$; TS $=$ total solids; $\mathrm{T}_{0}=$ control without any addition of MOLP; $\mathrm{T}_{1}=1 \%$ MOLP; $\mathrm{T}_{2} 2 \%$ MOLP; $\mathrm{T}_{3} 3 \% \mathrm{MOLP} ; \mathrm{T}_{4} 4 \% \mathrm{MOLP}$ 
increased in a dose dependent manner. The results showed the increasing level of calcium content of fortified whey drink by $10 \%, 19 \%, 31 \%$ and $47 \%$, respectively, as compared to the control, while the effect on potassium content of the drinks was non-significant (Table 2). Potassium content ranged from 1226 to 1245 $\mathrm{mg} / \mathrm{L}$ among different treatments and control. The elevation in calcium content of the experimental samples was due to the higher concentration of calcium in MOLP. The addition of MOLP at $4 \%$ level increased the iron content of the whey drink by $675 \%$ over the control.

The addition of MOLP at $1 \%$ level $\left(\mathrm{T}_{1}\right)$ increased the iron content from $0.17 \mathrm{mg} / \mathrm{L}$ to $44 \mathrm{mg} / \mathrm{L}$ which was 257\% higher than the control (Aney et al., 2009) while, studying the nutritional value of $M$. oleifera reported that the calcium, magnesium and iron content of $100 \mathrm{~g}$ dried MOLP was $2000 \mathrm{mg}, 1328 \mathrm{mg}$ and $28.2 \mathrm{mg}$, respectively. As recommendations of FAO, WHO 400 $\mathrm{mg}$ and $1200 \mathrm{mg}$ calcium is required on daily basis for the children of 1-3 years age and nursing women. Half of the total calcium requirement for nursing women may be easily and economically fulfilled by consuming just two glasses of $250 \mathrm{~mL}$ of whey drink supplemented with $4 \%$ MOLP, almost $75 \%$ of the calcium requirements of the children can be met by $250 \mathrm{~mL}$ of the fortified

Table 2. Effect of MOLP supplementation on mineral content of whey drink

\begin{tabular}{lllll}
\hline \hline Treatments & Calcium & Potassium & Magnesium & Iron \\
\cline { 2 - 5 } & \multicolumn{4}{c}{$(\mathrm{mg} / 100 \mathrm{~g})$} \\
\hline $\mathrm{T}_{0}$ & $268 \pm 0.93^{\mathrm{e}}$ & $1245 \pm 6.13^{\mathrm{a}}$ & $35 \pm 0.43^{\mathrm{b}}$ & $0.17 \pm 0.03^{\mathrm{e}}$ \\
$\mathrm{T}_{1}$ & $297 \pm 0.81^{\mathrm{d}}$ & $1231 \pm 2.48^{\mathrm{a}}$ & $38 \pm 1.24^{\mathrm{b}}$ & $44 \pm 0.09^{\mathrm{d}}$ \\
$\mathrm{T}_{2}$ & $320 \pm 0.54^{\mathrm{c}}$ & $1226 \pm 1.05^{\mathrm{a}}$ & $42 \pm 0.06^{\mathrm{b}}$ & $75 \pm 0.34^{\mathrm{c}}$ \\
$\mathrm{T}_{3}$ & $353 \pm 0.77^{\mathrm{b}}$ & $1238 \pm 0.78^{\mathrm{a}}$ & $45 \pm 0.31^{\mathrm{a}}$ & $99 \pm 0.52^{\mathrm{b}}$ \\
$\mathrm{T}_{4}$ & $394 \pm 1.06^{\mathrm{a}}$ & $1241 \pm 3.16^{\mathrm{a}}$ & $48 \pm 0.19^{\mathrm{a}}$ & $115 \pm 0.05^{\mathrm{a}}$ \\
\hline \hline
\end{tabular}

Means of triplicate experiment; means with same letters in a column are statistically non-significant; refer Table 1 for the detail of treatments. drink. M. oleifera leaves demonstrated higher vitamin A than carrots, more calcium and potassium than milk and banana with superior amino acid profile resembling to egg proteins (Juliani et al., 2009). Milk is not a complete food because of its lower iron and vitamin C contents, fortification of milk with iron is usually practiced in poor and malnourished countries. Most of the strategies involve the usage of sulphates of iron, which are unnatural and accelerate the oxidative breakdown (Fox and McSweeney, 2003). The iron requirement of 10 and $15 \mathrm{mg}$ per day for children and nursing women can be efficiently fulfilled by 250 and $300 \mathrm{~mL}$ of supplemented $\left(\mathrm{T}_{4}\right)$ whey drink. Feeding $M$. oleifera supplemented diet significantly improved the health status of school going babies and pregnant women in Senegal who gave birth to healthy babies (Juliani et al., 2009).

Feeding $10 \mathrm{~g}$ leaves to pregnant women may provide adequate concentration of essential micro nutrients to save them from becoming anemic, physically and mentally weak (Fahey, 2005). This could be the simple, economical and efficient way of preventing and correcting the anemic conditions of millions of children and women of the poor nations who cannot afford medication and expensive nutritional supplements.

Vitamins content of whey drink supplemented with M. oleifera leaves. The addition of MOLP at all levels significantly $(\mathrm{P}<0.05)$ increased the vitamin $\mathrm{B}_{5}, \mathrm{~B}_{2}, \mathrm{~B}_{6}$ and vitamin $\mathrm{C}$ content (Table 3 ). The increase in vitamins $\mathrm{B}_{5}, \mathrm{~B}_{2}, \mathrm{~B}_{6}$ and $\mathrm{C}$ was $158 \%, 372 \%, 193 \%$ and $50 \%$, respectively, in $\mathrm{T}_{4}$. The increase in vitamin content was due to the chemical composition of the MOLP which resulted in higher concentrations of these vitamins in the whey drinks. The addition of MOLP did not have any effect on free fatty acids and peroxide value of whey drink at all levels. The recommended daily allowance of vitamin $\mathrm{B}_{2}$ is 0.8 and $1.8 \mathrm{mg}$ for children

Table 3. Effect of MOLP supplementation on vitamin content and stability of whey drink

\begin{tabular}{|c|c|c|c|c|c|c|}
\hline Treatments & Vitamin $\mathrm{B}_{5}$ & $\frac{\text { Vitamin } \mathrm{B}_{2}}{(\mathrm{mg} /}$ & Vitamin E & Vitamin $\mathrm{C}$ & FFA \% & $\mathrm{PV}(\mathrm{meq} / \mathrm{kg})$ \\
\hline$\overline{\mathrm{T}_{0}}$ & $3.94 \pm 0.03^{\mathrm{e}}$ & $2.14 \pm 0.16^{\mathrm{e}}$ & $2.85 \pm 0.05^{\mathrm{e}}$ & $1.46 \pm 0.21^{\mathrm{e}}$ & $0.10 \pm 0.01^{\mathrm{a}}$ & $0.23 \pm 0.03^{\mathrm{a}}$ \\
\hline $\mathrm{T}_{1}$ & $5.59 \pm 0.14^{\mathrm{d}}$ & $4.16 \pm 0.24^{\mathrm{d}}$ & $3.91 \pm 0.18^{\mathrm{d}}$ & $1.69 \pm 0.19^{d}$ & $0.10 \pm 0.01^{\mathrm{a}}$ & $0.23 \pm 0.01^{\mathrm{a}}$ \\
\hline $\mathrm{T}_{2}$ & $7.12 \pm 0.11^{\mathrm{c}}$ & $6.06 \pm 0.42^{c}$ & $5.02 \pm 0.45^{\mathrm{c}}$ & $1.83 \pm 0.41^{\mathrm{c}}$ & $0.11 \pm 0.03^{\mathrm{a}}$ & $0.25 \pm 0.05^{\mathrm{a}}$ \\
\hline $\mathrm{T}_{3}$ & $8.68 \pm 0.31^{b}$ & $9.03 \pm 0.34^{\mathrm{b}}$ & $6.15 \pm 0.29^{b}$ & $2.01 \pm 0.12^{\mathrm{b}}$ & $0.11 \pm 0.01^{\mathrm{a}}$ & $0.26 \pm 0.02^{\mathrm{a}}$ \\
\hline $\mathrm{T}_{4}$ & $10.20 \pm 0.43^{\mathrm{a}}$ & $10.12 \pm 0.66^{\mathrm{a}}$ & $8.36 \pm 0.45^{\mathrm{a}}$ & $2.20 \pm 0.67^{\mathrm{a}}$ & $0.11 \pm 0.02^{\mathrm{a}}$ & $0.26 \pm 0.09^{\mathrm{a}}$ \\
\hline
\end{tabular}

Means of triplicate experiment; means with same letters in same column are statistically non-significant; refer Table-1 for the detail of treatments; FFA = free fatty acids; $\mathrm{PV}=$ peroxide value. 
and nursing women, $300 \mathrm{~mL}$ of supplemented whey drink at 2\% MOLP can meet $100 \%$ body's requirement with respect to this vitamin. 423 and $17 \mathrm{mg} / 100 \mathrm{~g}$, vitamin $\mathrm{B}_{2}$ and $\mathrm{C}$ were present in Ethiopian Moringa stenopetala (Price, 1985). Anwar et al. (2007) studied the effect of $M$. oleifera addition on oxidative stability of some vegetable oils and found that blend of soybean and sunflower containing $80 \%$ (MOO) has induction time from 1.12 to $5.99 \mathrm{~h}, 1.47$ to $6.22 \mathrm{~h}$, recorded the increase in oxidative stability $435 \%$ and $323 \%$, respectively.

Sensory evaluation. The results of sensory evaluation (Table 4) indicated that supplementation of MOLP up to $T_{2}$ level did not have any negative effect on texture and taste score. Texture and taste score of $T_{1}$ and $T_{2}$ were at par with the control $(\mathrm{P}>0.05)$. With the increasing increments of MOLP, the score for these two parameters decreased. Some panelists criticised $T_{3}$ and $T_{4}$ for relatively higher coarse texture. Level of criticism for $\mathrm{T}_{4}$ was not adverse as the people are already habitual of adding green leaves of coriander and other herbs in the butter milk. Quarcoo (2008) studied the development of $M$. oleifera based beverage and reported that addition of increasing concentration of M. oleifera leaf powder tended to make the colour greener and decreased the colour score. The low colour score was attributed to the uncommon green colour of the beverage; the lower concentrations were rated higher for this parameter. This problem could have been resolved by homogenising the supplemented whey drinks at high pressure. Homogenisation is commercially carried out to make the nectars and high fruit preparations homogenous and smooth (Spreer, 2005). Score for smell of all the treatments and control was non-significantly influenced from each other. The overall acceptability score of $\mathrm{T}_{4}$ was 6.9 out of 9 , which was more than $76 \%$ of the total score.

Table 4. Effect of MOLP supplementation on sensory characteristics of whey drink

\begin{tabular}{lllll}
\hline \hline Treatments & Texture & Taste & Smell & $\begin{array}{l}\text { Overall } \\
\text { acceptability }\end{array}$ \\
\hline $\mathrm{T}_{0}$ & $7.6 \pm 0.11^{\mathrm{a}}$ & $7.9 \pm 0.23^{\mathrm{a}}$ & $7.5 \pm 0.08^{\mathrm{a}}$ & $7.5 \pm 0.03^{\mathrm{a}}$ \\
$\mathrm{T}_{1}$ & $7.3 \pm 0.08^{\mathrm{a}}$ & $7.6 \pm 0.09^{\mathrm{a}}$ & $7.4 \pm 0.02^{\mathrm{a}}$ & $7.2 \pm 0.14^{\mathrm{a}}$ \\
$\mathrm{T}_{2}$ & $7.4 \pm 0.14^{\mathrm{a}}$ & $7.5 \pm 0.11^{\mathrm{a}}$ & $7.5 \pm 0.04^{\mathrm{a}}$ & $7.3 \pm 0.05^{\mathrm{a}}$ \\
$\mathrm{T}_{3}$ & $7.0 \pm 0.03^{\mathrm{b}}$ & $7.0 \pm 0.17^{\mathrm{b}}$ & $7.2 \pm 0.19^{\mathrm{a}}$ & $7.0 \pm 0.09^{\mathrm{b}}$ \\
$\mathrm{T}_{4}$ & $6.8 \pm 0.06^{\mathrm{b}}$ & $6.6 \pm 0.14^{\mathrm{b}}$ & $7.2 \pm 0.12^{\mathrm{a}}$ & $6.9 \pm 0.04^{\mathrm{b}}$ \\
\hline
\end{tabular}

Means of triplicate experiment; means with same letters in same column are statistically non-significant; refer Table 1 for the detail of treatments.

\section{Conclusion}

The addition of M. oleifera leaf powder at all concentrations improved the nutritional value of the whey drink. Protein and iron content significantly increased in the supplemented drinks. $300 \mathrm{~mL}$ of supplemented whey drink can fulfill $100 \%$ requirement of vitamin $\mathrm{B}_{2}$ of nursing women. Highly nutritious whey drink can be successfully prepared by the addition of MOLP up to $4 \%$ level; whey drink supplemented with MOLP should be homogenised for better sensory characteristics.

\section{References}

Aney, J.S., Tambe, R., Kulkarni, M., Bhise, K. 2009. Pharmacological and pharmaceutical potential of Moringa oleifera: a review. Journal of Pharmacy Research, 9: 1424-1426.

Anwar, F., Latif, S., Ashraf, M., Gilani, A.H. 2007. Moringa oleifera: A food plant with multiple medicinal uses. Phytotherapy Research, 21: 17-25.

AOAC, 2000. Official Methods of Analysis, American Association of Analytical Chemists, Inc., pp.131, $17^{\text {th }}$ edition, Washington, DC., USA.

Awan, J.A. 2000. Elements of Food and Nutrition, pp. 45-49, $2^{\text {nd }}$ edition, Unitech Communications, Faisalabad, Pakistan.

Fahey, J.W. 2005. Moringa oleifera: a review of the medical evidence for its nutritional, therapeutic, and prophylactic properties. Part 1. Trees for Life Journal, 1: 1-13.

Firestone, D. 1997. Official Methods and Recommended Practices of the American Oil Chemists 'Society. (AOCS), $5^{\text {th }}$ edition, AOCS Press Champaign, IL, USA.

Fox, P.F., McSweeney, P.L.H. 2003.Proteins. In: Advanced Dairy Chemistry, vol. 1, 1349 pp., $3^{\text {rd }}$ edition, part B, Kulwer Academic/Plenum Publishers, New York, USA.

Fuglie, L.J. 1999. The Miracle Tree: Moringa oleifera: Natural Nutrition for the Tropics, pp. 68, Church World Service, Dakar, revised in 2001 as The Miracle Tree: The Muliple Attributes of Moringa, $172 \mathrm{pp}$.

Jeong, S.M., Kim, S.Y., Kim, D.R. Jo, S.C., Nam, K.C., Ahn, D.U., Lee, S.C. 2004. Effect of heat treatment on the antioxidant activity of extracts from citrus peals. Journal of Agricultural and Food Chemistry, 52: 3389-3393.

Juliani, H.R., Fonseca, Y., Diatta, M., Diouf, B., Simon, J.E. 2009. Nutritional value of Moringa oleifera 
leaves from Senegal. African Journal of Traditional, Complementary and Alternative Medicines (AJTCAM), Abstracts of the World Congress on Medicinal and Aromatic Plants, Cape Town, Nov. 2008. http://journals.sfu.ca/ africanem/ index.php/ ajtcam/article/view/900

Kris-Etherton, P.M., Hecker, K.D., Bonanome, A., Coval, S.M., Binkoski, A.E., Hilpert, K. F., Griel, A.E., Etherton, T.D. 2002. Bioactive compounds in foods: Their role in prevention of cardiovascular disease and cancer. The American Journal of Medicine, 113 Suppl 9B: 71S-88S.

Larmond, E. 1987. Laboratory Methods for Sensory Evaluation of Foods, pp. 57-61, Publication 1637, Research Branch, Department of Agriculture, Ottawa, Canada.

Marwaha, S.S., Kennedy, J.F. 1998. Review: Whey pollution problem and potential utilization. International Journal of Food Science and Technology, 23: 323-326.

Middleton, E., Kandaswamy, C., Theoharides, T.C. 2000. The effects of plant flavonoids on mammalian cells: Implication for inflammation, heart disease and cancer. Pharmacological Reviews, 52: 673751.

Mohdaly, A.A., Iryna, S., Mohamed, F.R., Mohamed, A., Sarhan, A.M. 2011. Antioxidant potential of sesame (Sesamum indicum) cake extract in stabilization of sunflower and soybean oils. Industrial Crops and Products, 34: 952-959.

Naczk, M., Shahidi, F. 1998. Insoluble condensed tannins canola. In: Book of Abstracts of the $58^{\text {th }}$ Annual IFT Meeting, pp. 25-29, Atlanta, GA, USA.

Niketic, G., Marinkovic, S. 1984. The examination of the refreshing drink whey production possibility at aseptic conditions. Mijekarstov, 34: 105-109.

NNS, 2004. National Nutrition Survey 2003-2004. Planning Commission, Planning and Development Division, Govt. of Pakistan, Islamabad, Pakistan.

Price, M. 1985. Moringa oleifera; the miracle tree; http://www.moringa.com.my/moringa.htm.

Quarcoo, P. 2008. Development of Moringa oleifera Leaf Beverage. M.Sc. Thesis, Kwame Nkrumah University of Science and Technology. http:// dspace. knust.edu. gh: 8080/ jspui/ bitstream/ 123456789/644/1/PHYLLIS\%20Q UARCOO. pdf

Spreer, E. 2005. Milk and Dairy Products Technology, pp. 156-178, Marcel Dekker, New York, USA.

Walzem, R.L, Dillard, C.J., German, J.B. 2002. Whey components: Millennia of evolution creates functionalities for mammalian nutrition. Critical Reviews in Food Science and Nutrition, 42: 353 375. 